\title{
Algorithms in the Classes of Mathematical Education at the Early School Stage
}

\author{
Ewelina Kawiak (MA)
}

Doi:10.5901/jesr.2014.v4n4p11

University of Silesia - Faculty of Pedagogy and Psychology, Katowice, Poland

\begin{abstract}
Algorithm is a method which is applied whilst finding answers to mathematical problems. It determines the subsequent stages of proceedings in such a way that after their proper execution, the final score is always correct. In mathematical education algorithms are most often provided to students as the ready-made operation procedures imposed on learners. However, more and more often it is suggested that the traditional method of learning algorithms should be abandoned and students ought to be encouraged to discover algorithms for themselves. This article presents the opinions of pedagogy students about the possibilities of algorithm application during mathematics classes at the early school stage. It has also been studied whether the above-mentioned students believe that discovering the algorithms by young learners is at all feasible.
\end{abstract}

Keywords: Algorithms; mathematical education; early school education

\section{Introduction}

Mathematics develops the skills which are useful in everyday life of each person. Studying this subject creates excellent opportunities to develop cognitive processes. In Poland it is compulsory to attend school for students under 18. Studying mathematics is obligatory at all the stages of school education, beginning with kindergarten and ending with secondary school. Development of mathematical skills among children should be started as early as at the nursery school stage, and then, various forms of that development and its range should be gradually strengthened throughout three initial grades of primary school (Stucki, 1978). This study shows significant influence of parents on creative attitude of their children (Frania, 2010). Therefore it is worthwhile engaging parents in the development of mental abilities of their children.

The stages which are particularly important when it comes to teaching mathematics are the first and second stage of education, preceding the junior high school education. Provided that pupils master the fundamental notions and mathematical laws, arithmetic techniques and the skill of solving math problems while they are at the elementary school, they will encounter hardly any obstacles while acquiring further knowledge during the next educational stages (Sapeta, 2003).

Mathematical thinking is one of the basic skills which are acquired in the process of comprehensive education in elementary school. It is a teacher's job to motivate students to work and stimulate their mathematical initiative which includes several basic activities such as:

- recognizing and applying analogies,

- schematizing and mathematizing,

- defining, interpreting a new definition and its rational application,

- coding, formulating and rational usage of symbolic language,

- forming algorithms, rational application of algorithms,

- proving- deduction and reduction (Siwek, 2005).

A natural method of teaching and learning mathematics is problem solving, which consists in finding the answer to the question included in the exercise (Nowik, 2009).

The most common actions which are applied while problem solving are:

- formulating the task

- task solving and noting down its solution

- checking and evaluation the task solution (Suraj, Rumak, 1995).

There are many groups of methods which can be applied while solving mathematical tasks. One of their basic divisions is the selection of algorithmic methods and heuristic methods. The choice of the most suitable method of conduct is closely connected with the type of the task which needs to be solved. Algorithmic methods work best with tasks of a standard type, of a closed-ended category. Heuristic methods work best with solving non-standard and problem-type tasks. Efficient teaching of mathematics should include both heuristic and algorithmic approach, maintaining 
a suitable balance between them at various educational stages (Filip, Rams, 2000).

\section{Application of Algorithms in Mathematical Education-Theoretical Approach}

There are numerous definitions which determine what algorithms are. In the article below there will be presented only several of the selected theoretical views.

Algorithm is a universal method of effective problems solving within a certain category of tasks, characteristic features of which include:

- an unambiguous description of the method procedure, in other words, a detailed characteristic of particular stages of a problem solving process and unambiguous description of the system and the interdependence of its stages

- a detailed register of activities which assure the effectiveness of the method, in other words, the guarantee of a possibility of covering a particular stage of a solving process (Góralski, 1980).

Z. Krygowska observes that we apply a term of the algorithm prepared for a given task category, based on the predetermined collection of basic activities in order to define each plan of a finite sequence of activities selected from such a collection. Such a plan guarantees that carrying out the above mentioned activities in a predetermined order with the data that specify a particular task of this category leads to the successful task solving (Krygowska, 1979).

Algorithmic proceedings are closely connected with computer science, therefore some definitions refer directly to this field of science. Algorithm is a certain set of rules introduced to the computer system in order to have some calculations made (Hughes, 2001).

In accordance with the above mentioned definitions, there can be distinguished three major features which a given rule of conduct should fulfil in order to be named an algorithm:

- definite character or explicitness,

- extensiveness or versatility,

- $\quad$ effectiveness or reliability (Strzelczyk, 1989).

Teaching, especially when it comes to mathematics, is very frequently limited to students memorizing the information, which consequently negatively influences the cognitive processes (Cydzik, 1985). The approach to mathematical teaching which is present in a Polish school, is in favour of application of algorithmic methods. Algorithms of problem solving are offered to students in a ready-made form during the lesson.

Therefore, students' activity is limited solely to performing the predetermined procedure of conduct. Getting familiar with algorithmic patterns at school is associated with commands like 'memorize and practice' and their usage in further work is connected with situations like 'recognize and act' (Klus-Stańska, 2005).

Meanwhile, contemporary didactics strongly emphasises the fact that the situation when students independently discover the algorithms is a different matter thing in a cognitive sense than the situation in which they apply the algorithm learned previously (Klus-Stańska, 2005).

It is much more educatory for students if we create the situations when they

can independently formulate the algorithms as their own methods of task solving. It is possible at each stage of education because at each level of encounter with mathematics, its operational character can be noticed and at each level of mathematical teaching, the unique categories of mathematical thinking ought to be developed (Krygowska, 1979).

The algorithm which is devised by a student and formulated after the previous heuristic search, is better understood and will be remembered better. The research shows that the pupils willingly come up with their own methods of task solving, even in case of familiarizing strict procedures, such as the algorithms of written tasks or complex calculations (Dabrowski, 2013). The study conducted by the author, shows that the pupils in integrated early-school education do like mathematics classes and happily learn this subject (Kawiak, 2013).

It is the teacher's job to maintain this interest in mathematics among pupils and to organize the lessons in the most attractive manner to encourage pupils to work.

Furthermore, the lesson of mathematics should be structured in such a way that the algorithms could be practised in a flexible and multidimensional way (Klus-Stańska, Kalinowska, 2004). Teachers should take advantage of the school class potential and encourage pupils to formulate the algorithms for task solving in an unassisted way. The factor which optimizes independent and multifaceted cognitive performance of pupils is the usage of heuristics and algorithms system (Hemmerling, 1977). Applying heuristics is related to the commands like: 'make an attempt', 'think of a change' or 'test your own idea' (Klus-Stańska, 2005). In the table presented below there is a comparison of the basic features which characterize algorithms and heuristics. This factsheet will be useful to depict major differences between both courses of action. 
Table 1

\begin{tabular}{|l|l|l|}
\hline \multicolumn{1}{|c|}{ Division Criterion } & \multicolumn{1}{|c|}{ Algorithms } & \multicolumn{1}{c|}{ Heuristics } \\
\hline 1. Range of usage & very narrow & quite wide or very wide \\
\hline 2. Unreliability & zero & usually quite considerable \\
\hline 3. Conditions for success. & $\begin{array}{l}\text { the choice of a suitable } \\
\text { algorithm }\end{array}$ & $\begin{array}{l}\text { the choice of a suitable method, } \\
\text { individual traits of a user, pure chance }\end{array}$ \\
\hline 4. Resistance to disturbance or change of task conditions & zero & $\begin{array}{l}\text { quite considerable, depending on } \\
\text { individual traits }\end{array}$ \\
\hline 5. Clarity of instruction for the user. & very high & $\begin{array}{l}\text { low, especially with reference to particular } \\
\text { steps }\end{array}$ \\
\hline 6. Dependence of the final effect on the method. & very high & moderate, often hard to assess \\
\hline 7. Self-confidence and mental comfort of the user. & high, stabilized & $\begin{array}{l}\text { low, often minimal, with possible } \\
\text { outbreaks of enthusiasm }\end{array}$ \\
\hline 8. Emotional and personal involvement of the user. & slight & very high, often highest \\
\hline
\end{tabular}

Source: E. Nęcka, TRoP... Twórcze Rozwiązywanie Problemów, Kraków 1994, IMPULS.

\section{Algorithms at the Mathematics Classes at the Early School Stage in the Eyes of Pedagogy Students}

In October 2013 the survey was conducted at the Faculty of Pedagogy and Psychology, University of Silesia in Katowice.

A study sample consisted of students of the first and second year of pedagogy, in the field of Integrated Earlyschool and Nursery Education, at non-stationary, complementary graduate studies.

The results presented in the article are a part of wider empirical research conducted by the author. In this text there are presented only partial data obtained in the process of research, connected with the issues discussed in the article.

The purpose of presenting the fragment of the research was to determine the students' opinion on the possibilities of algorithms application at the mathematical education classes at the stage of integrated early school education. Additionally, the level of knowledge on algorithms among the respondents was checked.

The sample study of 150 respondents comprised of first-year students - 92 females (over 60\%) and the secondyear students- 58 females. All the respondents are the licenced teachers of integrated early school and nursery education. Some of them have to reconcile their studies with work duties. More than a half of the respondents do not work in their profession .

In accordance with the Polish law, holders of B.A. degree are entitled to work as teachers. The study revealed that 65 people out of all working respondents, work as school counsellors in various educational institutions (43\%). The most numerous group (88\%) works in kindergartens as the nursery education teachers. The smallest group of the respondents works in day-care centres. Table 2 displays data concerning the workplace of female students taking part in a survey.

Table 2: Workplace of female respondents. $(N=65)$

\begin{tabular}{|l|c|c|c|c|c|c|}
\hline & \multicolumn{2}{|c|}{ 1st year } & \multicolumn{2}{c|}{ Second year } & \multicolumn{2}{c|}{ Total } \\
\hline Work place & Number & Percentage & Number & Percentage & Number & Percentage \\
\hline Day-care centre & 0 & 0 & 2 & 7 & 2 & 3 \\
\hline Kindergarten & $\mathbf{3 4}$ & $\mathbf{9 4}$ & $\mathbf{2 3}$ & $\mathbf{7 9}$ & $\mathbf{5 7}$ & $\mathbf{8 8}$ \\
\hline Primary school & 2 & 6 & 4 & 14 & 6 & 9 \\
\hline
\end{tabular}

In the table, the responses of highest value are marked in bold.

Source: E. Kawiak, Heurystyczna metoda Georga Polya w oczach studentów pedagogiki [w:] T. Jablonsky, Studia Scientifica Facultatis Paedagogicae, Ružomberok, 2014.

Among the respondents there were women with varied work experience, ranging from one month to eleven years of work in a teaching profession. The most numerous group was made up of women teachers working in this profession for more than a year but less than 3 years (49\%). The least numerous group was the women with the longest work experience. Only $6 \%$ of respondents work as school counsellor for more than 5 years. Table 3 presents the data related to respondents' work experience. 
Table 3: Respondents' work experience. $(N=65)$

\begin{tabular}{|l|c|c|c|c|c|c|}
\hline & \multicolumn{2}{|c|}{ First year } & \multicolumn{2}{c|}{ Second year } & \multicolumn{2}{c|}{ Total } \\
\hline Work experience & Number & Percentage & Number & Percentage & Number & Percentage \\
\hline Less than a year & 15 & $\mathbf{4 2}$ & 4 & 14 & 19 & 29 \\
\hline $1-3$ years & 15 & $\mathbf{4 2}$ & 17 & $\mathbf{5 9}$ & $\mathbf{3 2}$ & $\mathbf{4 9}$ \\
\hline 3 5 years & 5 & 14 & 5 & 17 & 10 & 16 \\
\hline Over 5 years & 1 & 2 & 3 & 10 & 4 & 6 \\
\hline
\end{tabular}

In the table, the responses of highest value are marked in bold.

Source: Source: E. Kawiak, Heurystyczna metoda Georga Polya w oczach studentów pedagogiki [w:] T. Jablonsky, Studia Scientifica Facultatis Paedagogicae, Ružomberok, 2014.

Since the survey was conducted in October and the school year begins in September, the work experience of some respondents was merely a month. Nearly one third of respondents (29\%) are students just at the threshold of their career path. The respondents were supposed to answer a question: 'What are the algorithmic methods of solving mathematical problems?'. The significant majority of students correctly defined their character, indicating that they are methods of a closed category (87\%). The respondents enumerated: finiteness of the procedure, performing the sequence of specific operations step by step and their repetitiveness as the main features of algorithms.

$8 \%$ of the respondents believe that the algorithm is a method of the open category, using which one can allow themselves latitude in interpreting the procedure leading to the final result. The remaining $5 \%$ of respondents were not able to give an answer to that question.

The students were asked to choose a kind of task in which the application of algorithm is most effective. Most respondents indicated the typical mathematical problems. As many as $11 \%$ of all students claim that every mathematical task can be solved with the use of algorithms. The obtained results are displayed in Table 4.

Table 4: Answer to the question: Which type of mathematical tasks can be solved best with the algorithmic method? ( $\mathrm{N}=$ 150)

\begin{tabular}{|l|c|c|}
\hline Type of task & Number & Percentage \\
\hline Typical mathematical task & 99 & 66 \\
\hline Problem mathematical task & 35 & 23 \\
\hline All mathematical tasks & 16 & 11 \\
\hline
\end{tabular}

In the table, the responses of highest value are marked in bold.

Source: author's own survey (Kawiak, unpubl. 2014).

The surveyed students were not unanimous as regards the introduction of algorithms during mathematics classes in grades 1-3. Most respondents claim that the only proper form of algorithm implementation is presenting it in a readymade form by a teacher (76\%). They justified their choice arguing that offering students a ready-made mechanism, the likelihood of student making a mistake is minimal, which increases their chances of mastering the proper course of action.

Considerably fewer respondents appreciate the abilities of students in that scope. Only $24 \%$ of respondents believe that students can independently discover the algorithms for solving mathematical tasks. The female students, despite their dominant dislike to students' unassisted discovery of the algorithms, notice numerous cognitive and didactic virtues of this method. Table 5 depicts the positive effects which according to the respondents may be brought about by independent discovery of algorithms for solving mathematical tasks by pupils. 
Table 5: Answer to the question: What are in your opinion positive effects of unassisted discovery of the algorithms for solving mathematical tasks of problem category by pupils of grades $1-3$ ? $(\mathrm{N}=150$, number of responses $=725)$

\begin{tabular}{|l|c|}
\hline \multicolumn{1}{|c|}{ The effects of method application } & Number of responses \\
\hline It develops mathematical thinking & 113 \\
\hline It develops logical thinking & 101 \\
\hline It supports creative approach to the problem & 98 \\
\hline It supports pupils' independence & 136 \\
\hline It increases motivation to work & 72 \\
\hline It increases involvement & 90 \\
\hline It develops emotional resistance Total & 115 \\
\hline \multicolumn{1}{|c|}{} & 725 \\
\hline
\end{tabular}

In the table, the responses of highest value are marked in bold.

Source: author's own survey (Kawiak, unpubl. 2014).

For the respondents (136 responses), the most significant effect is the support of pupils' independence. According to university students, enabling pupils to be independent during mathematics classes can positively motivate pupils to work. Thanks to this, pupils will experience the position of 'a maker', will know that the completion of a task will depend greatly entirely on their performance. Another essential effect is development of pupils' emotional resistance to difficult situations (115 responses). In the opinion of the students, the failures which might take place during the attempts of task solving, may help pupils endure further the misfortunes happening to them, both at mathematics lessons and in everyday life.

The third most frequent response was development of mathematical thinking.

While devising their own strategies of action during task solving, pupils can stimulate cognitive processes responsible for understanding mathematical contents.

\section{Conclusions}

In the text there have been presented the results of author's own research concerning the opinions of pedagogy students regarding the possibilities of algorithm application during the mathematical education classes in grades 1-3 of elementary school. A substantial majority of the respondents presents basic knowledge of algorithms. The respondents are able to enumerate most significant characteristics of algorithmic methods of task solving, which are: determinacy, finiteness and repetitiveness. The students can also correctly determine which type of tasks the algorithms can be used with at the early-school stage of mathematical education.

Despite the fact that contemporary didactics emphasises the validity of unassisted discovery of task solving methods by pupils, majority of respondents claim that the best method of introducing the algorithm is by presenting pupils with a ready-made form of it. This fact may be caused by the respondents being accustomed to the form of lesson work dominant in contemporary school, wherein the activity and responsibility for the didactic process lie mainly on the side of a teacher. In all likelihood, the university students who participated in the survey, have also experienced mathematical education in the above mentioned form. Regardless of this, the respondents notice numerous advantages which occur when pupils are given freedom to discover their own methods of mathematical task solving. This fact allows us to assume that the respondents in their professional work will make attempts to alter the current state of affairs and will be ready to let their pupils try and find their own formulas of task solving.

\section{References}

Cydzik, Z. (1985). Matematyka dla klasy pierwszej szkoły podstawowej: przewodnik dla nauczyciela. Zeszyt 1. Warszawa: Wydawnictwa Szkolne i Pedagogiczne.

Dąbrowski, M. (2013). Za trudne, bo trzeba myśleć. Warszawa: Instutut Badań Edukacyjnych.

Filip, J., Rams, T. (2000). Dziecko w świecie matematyki. Kraków: Impuls.

Frania, M. (2010). Selected Aspects of the Family Environment of Creative People as Exemplified by Research Conducted among Academic Youth. The New Educational Review. vol. 20. No. 1. Toruń: Wydawnictwo Adam Marszałek.

Hemmerling, W. (1977). Kierowanie rozwiazywaniem zadań matematycznych w klasach początkowych, Koszalin: Instytut Kształcenia Nauczycieli i Badań Oświatowych.

Hughes, J. (2001). Encyklopedia powszechna. Warszawa: Muza.

Kawiak, E. (2014). Heurystyczna metoda Georga Polya w oczach studentów pedagogiki. [in:] Jablonsky, T., Studia Scientifica Facultatis 
Paedagogica. Ružomberok: Universitas Catholica Ružomberok.

Kawiak, E. (2013). Mathematical education in the opinion of the students of integrated early-school education - a study report. "Journal of Educational \& Social Research", vol 3, no. 7, pp. 69-75.

Klus-Stańska, D., Kalinowska, A. (2004). Rozwijanie myślenia matematycznego młodszych uczniów. Warszawa: Wydawnictwo Akademickie „Żak”.

Klus-Stańska, D., Nowicka, M. (2005). Sensy i bezsensy edukacji wczesnoszkolnej. Warszawa: Wydawnictwa Szkolne i Pedagogiczne. Krygowska, Z. (1979). Zarys dydaktyki matematyki, cz. 1. Warszawa: Wydawnictwa Szkolne i Pedagogiczne.

Nęcka, E. (1994). TRoP... Twórcze Rozwiazzywanie Problemów. Kraków: Impuls.

Nowik, J. (2009). Kształcenie matematyczne w edukacji wczesnoszkolnej. Opole: Wydawnictwo Nowik.

Sapeta, J. (2003). Metoda zautomatyzowanego rachowania oparta na układzie liczb na palcach. Kraków: Impuls.

Siwek, H. (2005). Dydaktyka matematyki: teoria i zastosowania w matematyce szkolnej. Warszawa: Wydawnictwa Szkolne i Pedagogiczne.

Strzelczyk, U. (1989). Możliwości zastosowania algorytmów w początkowym nauczaniu ortografii. Katowice: Instytut Kształcenia Nauczycieli - Oddział Doskonalenia Nauczycieli w Katowicach.

Stucki, E. (1978). Rozwijanie zdolności matematycznych w nauczaniu początkowym. Bydgoszcz: Wyższa Szkoła Pedagogiczna.

Suraj, Z., Rumak, T. (1995). Algorytmiczne rozwiązywanie zadań i problemów. Rzeszów: Wydawnictwo Oświatowe FOSZE. 